\title{
JUDICIAL REFORMS IN CHINA: THE WAY OF STRENGTHENING THE JUDICIAL INDEPENDENCE
}

\author{
${ }^{1}$ Mohammad Saiful Islam, ${ }^{2} \mathrm{Xu}$ Xin \\ ${ }^{1}$ Institute for Advanced Judicial Studies (IAJS), Beijing Institute of Technology; \& Department \\ of Law, International Islamic University Chittagong (IIUC), E-mail: lawsaiful@gmail.com \\ ${ }^{2}$ Institute for Advanced Judicial Studies (IAJS), \& Professor, School of Law, Beijing Institute of \\ Technology, E-mail: xuxin.net@163.com
}

\begin{abstract}
The idea of judicial independence and Chinese courts are the parallel subject matter of discourse among the scholars in several fields in place of either judicial independence strengthen or restricted as Chinese authority continually pushes numerous judicial reform strategy year to year. The westerns, frequently, utter China's courts are beyond enjoying appropriate independence to decide judicial verdicts solely and independently. Conversely, the Chinese leaders enunciate they entirely extempore to swallow the Western impresses as they are a cradle of rescinding the unique Chinese features. This paper, broadly, attempts to address the design of several rounds of judicial reform policy till nowadays as a means of strengthening the independence of courts. The study catches that the Chinese authority invests rigorous reform efforts to the efficient management of court administrations; to recruit better-qualified judges; to reduce internal interference from party leaders and courts seniors. They also amended laws to progress decisional independence that will extend the Chinese judiciary closer to unaffected judicial independence.
\end{abstract}

Keywords: Strengthen Independence; Reform Policy; Qualified Judges; Efficient Mechanisms; CCP's Interference.

\section{Introduction}

China's judiciary or court system is frequently blamed for the non-existence of practical judicial independence. Ordinarily, the typical approach of most Western jurists regards the Chinese judiciary is "Courts are one of a number of state bureaucracies with the power to resolve disputes, and lack significant oversight powers over other state actors". The Constitution mandates that China should be governed with the rule of law.( Chapter I, Art.5, s.1 of The Constitution of the People's Republic of China (1982) (hereafter "The Constitution of China"). It is largely recognized, an independent judiciary is a preeminent basis for defending the rule of law. ${ }^{2}$ The aim of the rule of law necessitates "the development of a judicial system that is relatively autonomous of the executive and legislative powers of government". ${ }^{3}$ China's government has deeply realized the significance of an independent adjudication process to enhance the rule of law, guaranteeing human rights, expanding economic growth, and maintain

\footnotetext{
${ }^{1}$ (Liebman, 2007: p. 621)

2 (Keyuan, 2002: p. 1046)

3 (Orts, 2001: p. 99)
} 
social justice and fairness. Simultaneously, the Chinese Communist Party (CCP) has itself recognized the low standing of judges and courts, the deficiency of judicial independence as deflation the efficacious formation of China's form of the rule of law. Consequently, Chinese authorities continuously attach various judicial reforms, as they have constantly been enhancing credibility and independence in the adjudication process. They have hardly been tried to development of justice by extending the stage to stage reforms of court administration and work mechanism with the intention of shape an independent, efficient, fair, and authoritative Socialist judicial system. Although, typically, China does not recognize western viewpoint or influence and they implement reform agenda with upholding national characteristics. The Supreme People's Court (hereafter "SPC") has accredited the necessity to scrutiny overseas in planning court reforms. ${ }^{4}$

By considering efforts to strengthen judicial independence, judicial reforms have received enormous attention in both China and Western over the last two decades as judicial reforms are one of the fragments of the inclusive legal reforms in China. The aims of this study have designated to expand the current pieces of literature regarding judicial reform as means of strengthening judicial independence from the Chinese context and encouraging an enthusiast of people to unfathomable study regarding judicial independence with Chinese features. The study does not take into an abysmal discussion on a fifth five-year reform plan that might generate new literature in the future on this area; it's limitations of this scholarship.

\section{Methods}

The study embraces mainly the qualitative method with the analytical approach. The research drives based on the description so that the present study is estimated to achieve a comprehensive, systematic, and complete depiction of the objective of the study. The study moves forward with an analysis of the primary legal resources and secondary legal resources that play a vital role in reaching the ultimate findings of the study. This study has adopted primary resources covering the Constitution of China, Judges Law of China, Organic Law of the People's Courts, SPC's reform order, and other legal rules concerning extended judicial reform in China. Besides primary resources, the study has engaged secondary sources comprising books, trustworthy journal articles, convenient online-based periodicals, newspaper articles, media reports, and Internet documents.

4 The People's Republic of China, "The Second Five-Year Reform Plan of the People's Courts (2004-2008)," Supreme People's Court of the People's Republic of China. 


\section{Results and Discussion}

\subsection{Judicial Independence in Brief}

Judicial independence ${ }^{5}$ is a multifaceted idea, ${ }^{6}{ }^{7}$ and "one of the least understood concepts". ${ }^{8}$ It varies from country to country, subject to the legal system, government system, traditions, and political culture. ${ }^{9}{ }^{10}$ Usually, judicial independence denotes judges' liberty to perform judicial functions without any explicit or implicit meddling from the outside, mainly from the executive of the government and judges' freedom from the internal influence of senior colleagues. It wants that judiciary should not be subject to regulations of the executive, and judges should enjoy "protection from any threats, interference, or manipulation which may either force them to unjustly favor the government or subject themselves to a penalty for not doing so". ${ }^{11}$ It requires that "a judge adjudicates without fear or favor, even in the face of a contrary view widely held by others, whether judicial colleagues, government, the public, the media, or interest groups". ${ }^{12}$ The conventional concept of judicial independence preserves four elements: personal and substantive independence as of 'individual independence of judges' and internal and collective independence as of the 'institutional independence of the judiciary' as an autonomous body. ${ }^{13} 141516$

\subsubsection{Individual Independence of Judges}

Universal Declaration on the Independence of Justice 1983 mentions that a judge shall be resolved cases impartially in acquiescence with 'assessment of the facts' and 'understanding of the law' without any direct or indirect "restrictions, influences, inducements, pressures, threats or interferences". 171819 'Personal independence' contains the tenure of judicial office is sufficiently

\footnotetext{
5 M S Islam, "Independent Judiciary: Nature and Facets from the International Context," International Journal of Ethics in Social Sciences 6, no. 2 (2018): 15-32.

6 Shimon and Jules Deschênes Shetreet, Judicial Independence: The Contemporary Debate (Netherlands: Martinus Nijhoff Publishers, 1985).

7 (S. Shetreet, 2011: p. 3)

8 (Larkins, 1996: p. 607)

(Hailsham, 1978)

(Salzberger, 1993: p. 350)

(Larkins, 1996: p. 608)

(Council, 2016: p. 6)

(S. Shetreet, 1985: p. 598)

4 (Ferejohn, 1999: p. 355)

15 (Akkas, 2002: p. 15)

16 Shetreet, "Judicial Independence and Accountability: Core Values in Liberaldemocracies."

17 The People's Republic of China, Universal Declaration on the Independence of Justice 1983 Art. 2.02, 1983.

18 The People's Republic of China, UN Basic Principles on the Independence of the Judiciary (1985), Art. $2,1985$.
} 
secured until a required retirement age, and the standings of services comprising transfer; satisfactory remuneration; pensions privileges; travel budget should not be under the regulations of the government, especially the executive. ${ }^{20} 2122$ 'Substantive independence' denotes that the application of the judicial duties and other official functions regarding judicial decision-making judges are individually subject to no other authority but the law and their conscience. ${ }^{23} 24$

\subsubsection{Institutional Independence of the Judiciary}

The judicial independence should not appear only judges' independence from "executive pressures or legislative interferences", but then it must also include the judges' independence from his judicial colleagues and superiors' influence. ${ }^{25}$ The view of 'collective independence' labels substantive, administrative, financial, and procedural freedom that is a concern to the actual performance of the judiciary's operation as a body. If the court is subject of dependent to the executive, legislature, or other institutions for its administrative and financial process this might unpleasantly effect on the performance of individual judges' official duties and judicial functions. ${ }^{26} 2728$ 'Internal independence' includes that judges be free from directives or pressures of judicial lords and those who possess authority in the court's administration, for instance, the Chief Justice or the head of the branch in the court. ${ }^{29}$ However, all influences and interfering of the higher court have not measured the destruction of the freedom to internal independence of judges like the supervision of the higher court and court's precedents.

19 The People's Republic of China, Beijing Statement of Principles of the Independence of the Judiciary (1995), Art. 3(A)., 1995.

20 (S. Shetreet, 1985: p. 598-599)

21 MP Singh, "Securing the Independence of the Judiciary: The Indian Experience," Indiana International Comparative Law Review 10, no. 249 (2000).

22 (S. Shetreet, 2011: p. 15)

23 Shimon Shetreet, "The Administration of Justice: Practical Problems, Value Conflicts AndChanging Concepts," University of British Columbia Law Review 13 (1979): 57.

24 (S. Shetreet, 1985: p. 630)

25 (S. Shetreet, 2011, p.3)

26 (S. and J. D. Shetreet, 1985:p. 644)

27 (Ferejohn, 1999: p. 355)

28 (S. Shetreet, 2011: p. 16)

29 (S. Shetreet, 2011: p. 16-17) 


\subsection{Judicial Reforms in China: Way to Strengthen its Independence}

\subsubsection{Primary Reforms}

"Judicial reforms is a key term in China's jurisprudence", and the Chinese court has constantly pushed for supplementary reforms. ${ }^{30}$ After the end of the cultural revolution (19661976), the CCP has implemented wide-ranging several rounds legal and judicial reforms 313233 ${ }^{34}$ initiatives with the objective to create the judiciary more independent. ${ }^{35}$ The CCP has adopted various strategies to improve a professional and independent judicial organization as the focal path for dispute resolution. Consequently, the CCP progressively delegated the judicial authority to the courts and self-abstained its influence on the ordinary case management, which give rise to in the ongoing development of adjudicative independence. ${ }^{36}$ In the 1980 s, China started judicial reform, with the vital objective of founding a State ruled according to the law, ${ }^{37}$ confirming professionalism in judicature, concentrating on increasing the functions of the court trial, enlightening prosecutor defense functions, and training professional judges. ${ }^{38}$ In the late 1990s, China's leadership improved endeavors to strengthen the judicial system that received enlarged attention of the courts' role. ${ }^{39}$ Subsequently, the SPC delivered some reform agenda that highlighting the construction of professional judiciary, "separation of functions, and on trials and adjudication". ${ }^{40}$ Moreover, in 1998, the SPC ordered every court to launch a separate case filing division distinct from the trial division as a part of the separation of court functions in the matter of filing, adjudicating, and supervising. ${ }^{41}$

(He, 2017: p. 135)

State Council, "Whitepaper on Judicial Reform in China."

32 State Council The People's Republic of China, "White Paper: Judicial Reform in China, Information Office of the State Council," Information Office of the State Council.

33 The People's Republic of China, "Whitepaper on Court Reform in China," Supreme People's Court of the People's Republic of China.

34 The People's Republic of China, "Whitepaper on Chinese Court Judicial Reform (2014-2018)," Supreme People's Court of the People's Republic of China.

35 (Feng, 2016: p. 1)

36 (Yanrong, 2018: p. 3)

37 Xin Chunying, "What Kind of Judicial Power Does China Need?," International Journal of Constitutional Law 1 (2003).

38 Council, "Whitepaper on Judicial Reform in China."

39 (Liebman, 2007: p. 624)

40 (Woo, 2017: p.247)

${ }^{41}$ Ibid. 


\subsubsection{Reforms Before 2013}

Before 2013, CCP issued three "Five-year Reform Programs for the People's Courts" respectively in 1999,2005 , and $2009 .^{42}$ In 1999, following the grip of "rule of law", the SPC declared first five-year (1999-2003) reform strategy ${ }^{43}$ to shape a "fair, open, highly effective, honest, and well-functioning" judicial system ${ }^{44}$ with planning of 50 goals. ${ }^{45}$ The reform program was designed with aiming to (1) reform of adjudicating methods aligned on the "principle of open trial"; (2) to institute the adjudicating administration mechanism concentrating on "strengthening the responsibility of judges"; (3) to manage internal institutions of the courts splitting adjudicating personnel and administrative personnel in the judiciary; (4) to provide a high qualified judges; (5) to "improve the efficiency of adjudicating work"; (6) to progress the supervisory methods safeguarding the integrity and fairness; and (7) to reforms the organizational system of the courts, management, and funds. ${ }^{46}$ Under this reform policy, the significant measures comprised among others: introducing single judge trial procedure for higher court efficiency, the formation of rule of evidence and the parting of the acceptance of cases from adjudication within the courts, ${ }^{47}$ establishing enforcement offices at all ranks of courts, and requiring full pledge law school degree for new judges.

The second five-year court reform plan of 2004-2008 was issued in October $2005{ }^{48}$ The reform plan was listing 50 goals intended to "strengthen the competence of judges and the professionalism of the court system", 49 ensuring judicial neutrality and fairness, improving judicial credibility, promoting judicial transparency and professionalism. ${ }^{50}$ The concrete measures were: the principle of presumption of innocence recognized and applied in court hearings, judicial review of administrative decisions. In 2006, around 17,018 administrative decisions were affirmed illegal or invalid. As a result of the evaluation, 34 percent of decisions of the governments or their branches made changes, and courts continued only 18 percent of the

\footnotetext{
42 The People's Republic of China, "Whitepaper on Judicial Reform of Chinese Courts," Supreme People's Court of the People's Republic of China.

43 (Liebman, 2007: p. 624)

44 (Gechlik, 2005: p. 98)

45 The People's Republic of China, The Five-Year Program for Reform of the People's Courts, Gazette of the Supreme People's Court of the People's Republic of China (Gazette of the Supreme People's Court of the People's Republic of China, 1999).

46 (Keyuan, 2002: p.1045)

47 (Liebman, 2007: p. 625)

48 The People's Republic of China, "Second Five Year Reform Program for the People's Courts (2004-2008)," Supreme People's Court of the People's Republic of China.

49 (Liebman, 2007: p. 625)

50 The People's Republic of China, "Second Five Year Reform Program for the People's Courts (2004-2008)."
} 
total administrative decisions. Improved selection and promotional mechanism for judges. Based on these two round reforms strategy, among other significant progress, Liebman identified three notable development trends coming from lower courts. First, lower courts judges are increasingly considering other courts for assistance when they are meeting novel or difficult cases "rather than to party-state officials or court superiors". Second, judicial networks nurture legal innovation, and some local courts have involved in significant legal novelty. Third, courts have become "the place for airing a range of grievances" even though Chinese courts are not a forum for deciding public rights. ${ }^{51}$

The third five-year court reform plan was 2009-2013 promulgated in 2009. ${ }^{52}$ The reform plan was formulated to develop "working mechanisms, maintaining social fairness and justice", satisfying prospects of the ordinary people vis-à-vis the judicial work, ${ }^{53}$ strengthening human rights protection, and enhancing judicial capabilities. ${ }^{54}$ In the course of this duration, judicial reforms of the people's courts were made on the following aspects: improve and reform the operating mechanisms for the judicial functions, reform and improve the civil, criminal, and administrative trial system, reform the trial organization. ${ }^{55}$ In this reform period, separation of filing, trial, and execution of cases were made. All levels of people's courts have established "case-filing tribunals, execution bureaus and other departments" along with the original civil, criminal, and administrative adjudication courts. Case-filing, trial, and execution are controlled distinctly by different offices independently and workout mutual-check functions to make sure the impartial application of adjudicative and execution authority. ${ }^{56}$ The qualified judges are required and mandatory to perform judicial functions independently. Thus, China has incessantly improved judicial capabilities through applying a "unified national judicial examination system", and strengthened professional and ethical training. ${ }^{57}$

51 (Liebman, 2007: p. 631-633)

52 The People's Republic of China, "Notice of the Supreme People's Court on Issuing the Third Five-Year Reform Outline for the People's Courts (2009-2013)," Supreme People's Court of the People's Republic of China.

53 Ibid.

54 Council, "Whitepaper on Judicial Reform in China."

55 The People's Republic of China, "Notice of the Supreme People's Court on Issuing the Third Five-Year Reform Outline for the People's Courts (2009-2013)."

56 Council, "Whitepaper on Judicial Reform in China."

57 Ibid. 


\subsubsection{Fourth Five-year Reform (2014-2018): Strengthen Personal Independence}

The SPC dispensed the fourth five-year reforms plan for the courts. ${ }^{58}$ In October 2014, the central committee of CCP in its fourth plenary accentuated the necessity for widespread judicial reforms to progress judicial efficiency and fairness. With the purpose of execution of the spirit of the $18^{\text {th }}$ National Congress of the Party and fourth plenary sessions of the $18^{\text {th }}$ central committee, opinions of SPC on Comprehensively Deepening the Reform of the People's Courts were framed for the fourth five-year reform outline (2014-2018). ${ }^{59}$ The major outlines of the reforms of the People's Courts were: (i) Establish an appropriate judicial system; (ii) Enhance the in-house power spreading of the people's court by reforming the case acceptance, review, case quality assessment, implementation, and perfection of the judicial assistance system; (iii) Establish an open, transparent, and the convenient judicial mechanism; (iv) Promote the regularization, and professionalization of court personnel through reforming the classification of court personnel management system; the method for the selection of judge; judges' performance assessment method; (v) Ensuring exercise of judicial authority of the people's courts independently, and fairly consistent with law by reforming and improving unified management of "court personnel below the provincial level"; inaugurate working mechanisms to check interfering with judicial actions; the protection mechanisms for judges to accomplish their legal obligations; and reform of the inside institutes of the people's courts. ${ }^{6061}$

Based on the opinions of the SPC and outline of the fourth five-year reforms plan, the momentous endeavors of reforms were made in these periods. In order to conserve the unification of the legal system, the SPC has established several circuit tribunals. ${ }^{62} 63$ The several reforms have been made to strengthen the personal independence of judges. First, the professional judge selection committee has been established at the provincial stage to be accountable for the choice of judges for the entire province. Second, to progress the job safety of judges as the professionalizing judiciary. Third, a distinct salary scheme has been established for judges conforming to the single post order for judges in the Judges Law. ${ }^{64}$ The SPC has also

58 The People's Republic of China, “The Supreme People's Court Issues Its Newest Five-Year Reform Plan for the Courts," Supreme People's Court Monitor.

59 The People's Republic of China, "Opinions of the Supreme People's Court on Comprehensively Deepening the Reform of the People's Court: Outline of the Fourth Five-Year Reform of the People's Court (2014-2018),"

60 Ibid. Supreme People's Court of the People's Republic of China.

61 (Wang, 2017: p. 48)

62 The People's Republic of China, "Whitepaper on Judicial Reform of Chinese Courts."

63 The People's Republic of China, "Whitepaper on Court Reform in China."

64 (The People's Republic of China, 2015b: p. 6-7) 
tried to establishing open and public trials to legitimize the court works and transparency. According to the work report of China's SPC 2014, in 2013, the SPC published about 45,000 trial proceedings on public media, including high-profile ones. Also, the SPC released a website to publish courts' judgment documents. Hitherto about 3900 SPC judgments and 1.65 million ones from local courts have been published. ${ }^{65}$

\subsubsection{Strengthen Internal Independence}

The SPC has understood the problem and criticisms regarding the internal independence of judges; thus, it attempted to progress it. The one definite objective of the fourth five-year reform was to progress the functional mechanisms of adjudicative power. SPC's white paper remarks, to improve the internal process mechanisms of adjudicative power, courts "optimized the personnel allocation, reformed their internal organs, and canceled approval requirement" for "handling of major, difficult and complicated cases by the presidents or presiding judges of such courts in person". ${ }^{66}$ In these circumstances, numerous specific actions have been implemented to enhance the internal independence of judges. First, the primary and intermediate people's courts shall have established a relatively fixed adjudication team comprising of judges, judge assistants, court clerks, and other supporting personnel. Second, remodeling the signature mechanism of judgments. As per reform, except cases discoursed and decided by the adjudication committee, the president, vice president, and presiding judges shall not sign, verify, approve, or deliver the judgments for cases that they have not directly contributed in. ${ }^{67}$ Third, the president, vice presidents, and adjudicative committee members "shall directly form a panel to hear major, difficult and complicated cases" 6869 This endeavor to make the general experience about the hearing of cases and to reduce the approval or consent of senior judges without hearing the cases.

Fourth, the people's courts shall build specialized judges' councils comprising civil, criminal, and administrative judges to deliver an advisory opinion to the panel to properly understand and application of laws. ${ }^{70}$ Fifth, refining the supervision system of adjudication. Under this reform, the supervisory authority of the president, vice president, and presiding judge

65 The People's Republic of China, "Highlights of Work Report of China's Supreme People's Court 2014," Supreme People's Court of the People's Republic of China.

${ }^{66}$ (The People's Republic of China, 2016, Part IV)

67 The People's Republic of China, "SPC's White Paper Remarks, the Direct Adjudication by a Sole Judge or a Panel in the Shanghai Courts Reach 99.9 per Cent, and Only 0.1 per Cent Referred to the Discussion by the Adjudication Committee," Supreme People's Court of the People's Republic of China.

68 Ibid.

${ }^{69}$ (Feng, 2016: p. 10)

70 (Feng, 2016: p. 10) 
will be constrained so as to he may neither provide his tendentious opinions on cases that he does not participate in hearing nor straight deny the views of a sole judge or a panel. Sixth, reform the adjudication committee system and strengthening the macro-direction functions of the committee. The adjudicative committee will primarily discuss the laws application issue of difficult, major, and complicated case except for the exception of complicated and major cases regarding national security, diplomacy, social stability, and those required by law. ${ }^{71} 72$ Scholars have noted that after these various dynamic reform agenda, interference to judges from the senior colleagues in the same court can be significantly reduced. ${ }^{73}$

\subsubsection{Strengthen Collective Independence}

One of the vital objectives of the fourth five-year reform is to progress the administration of the judiciary and explore the enhancement of court organization. The significant reforms were unified management of court organization and administration with the appointment mechanism of judges. As mentioned in the Whitepaper, a key area of improvement is "to push forward the unified management of personnel, funds, and properties of local courts below the provincial level" to designate that local courts are not belonging to local governments but belonging to the Central Government. ${ }^{74}$

In these aspects, numerous particular reform measures have been made. First, as a unified way, the organizational establishment of courts will be mainly directed by their corresponding provincial organization departments with the coordination of the high people's courts. Second, presenting a unified management system of court personnel, in which the judge in local court below the provincial level shall be selected, appointed, managed, and removed in line with "statutory procedures by the provincial authority". Also, under a unified method, potential judges shall "be recruited by the high people's courts". New judges shall be nominated by "the judges' selection committee at the provincial level" ......, and will be employed and removed according to statutory processes "upon nomination by the provincial authority". Third, introducing the unified system of courts funds management, in which "necessary funds of the local courts below the provincial level will be fully guaranteed by the Central Government and the provincial

\footnotetext{
Ibid.

The People's Republic of China, "Whitepaper on Judicial Reform of Chinese Courts."

(Feng, 2016: p. 10)

${ }^{74}$ Ibid.
} 
governments within the budgets". And "the relevant budget funds will be appropriated by the centralized payment system of the national treasury". ${ }^{75}$

As a measure of enhancing the transparency of court proceedings and building trust in courts, many Chinese courts ${ }^{76}$ have lately requested citizens to enjoy a date in a courtroom. The judge of court supposed, fascinating more individuals to present in court hearings is a way of guaranteeing justice and increasing transparency in trials. Also, it aims to improve legal and judicial awareness among citizens. ${ }^{77}$ Above reforms regarding unified management method of courts, funds and judges seem technique to reduce the local protectionism as all courts are set up by the State. The transparent and merit basis selection and appointment process of prospective judges is required to enhance judicial independence. Thus, these reforms are ways to strengthen the collective independence of judges in order to perform judicial functions smoothly and impartially.

\subsubsection{Fifth Five-year (2019-2023) Reform Plan}

On 27 February 2019, the SPC issued a new policy and guideline on judicial reform for the five years from 2019-2023. The aim of this policy, the establishment of the modern smart court in which courts should make progress in the well use of technologies, counting artificial intelligence and big data to serve more efficient legal facilities for litigants. The guideline is alienated into 10 critical sectors with 65 reform measures that have been fragmented in 160 specific tasks. It instructions Chinese courts to explore the method of delivering legal documents online along with building a litigation system making use of mobile phones to advance judicial efficiency. ${ }^{78}$ This reform plan also emphasizes on the maintaining judges' internal independence to decide cases independently out of interference.

The policy declares that judges should be responsible for their cases, and case hearing shall free from interruption. However, there are two grounds in which the court presidents and chief judges could be permissible to follow up and provide advice. The two grounds are: first, if the disputes comprise a "large number of litigants"; second, the case's outcome may "influence

75 (Feng, 2016: p. 12-13)

76 The People's Republic of China, "The Intermediary People's Court of Yinchuan, Capital of Ningxia Hui Autonomous Region, Is One of the Courts That Promoted the Invitation to Attend People in Court Hearings.," Chinese Courts Invite Citizens to Courtrooms.

77 Ibid.

78 Hu Shihao, "Supreme Court Issues Five-Year Plan on Judicial Reform," in Supreme People's Court Specials, 2019. 
social stability". ${ }^{79}$ In this position, further explanations are required through rules about the specific number of litigants to consider large number of litigants and also should plainly determine the nature of influence on social stability to minimize interference. The proposed reform confirms that the monitoring method and advice must be written with record to preclude them from mistreating power. ${ }^{80}$ However, the director of the SPC's judicial reform office denotes that the details scope and nature of the monitoring process of the courts' presidents and chief judges are still inattentive from the specifics, and the SPC would provide a more precise list of powers in the reform periods. ${ }^{81}$

\subsubsection{Modification of Judges Law to Progress Decisional Independence}

The communal insight is that judges' personal freedom in China has not been completely recognized. The substantive independence of judges is affected because they cannot resolve cases solely in line with the law, facts, and directions of his conscience. There are several other aspects they need to meditate. ${ }^{82}$ The Chinese authority randomly makes efforts to advance judicial standards, efficiency, and an independent adjudication process. In this regard, China has been adopted revisions to the Judges Law $^{83}$ as a portion of the country's initiative to progress judicial reform. The revised Judges Law accumulates substantial provisions regarding judges' appointment qualification, promotion, and adjudication process to progress judicial quality, efficiency, and independence.

According to the modified law, new-fangled measures are: first, new-judges must pass the national unified qualification exam for legal professionals ${ }^{84}$. This measure shall act to enhance and strengthen judicial independence and provide quality judgments. For the reasons, welleducated judges develop professional identities, and better-qualified judges progressively consider other judges and courts in deciding novel and difficult cases rather than Party directors. $^{85}$ Moreover, other reasons: (i) the mandatory pass in the professional qualification exam could help to select and recruit the well-informed in the legal field and qualified judges at entry-level. (ii) It promotes merit basis selection priority rather than lobbing and political import.

79 The People's Republic of China, "Supreme Court Issues Five-Year Plan on Judicial Reform : Highlights of 2019 SPC Two Sessions (Hereinafter SPC Latest Five-Year Plan)," Supreme People's Court of the People's Republic of China.

80 Ibid.

81 Shihao, "Supreme Court Issues Five-Year Plan on Judicial Reform."

82 (Feng, 2016: p. 14)

83 (Judges Law of the People's Republic of China amended on April 23, 2019)

84 (Judges Law of the People's Republic of China amended on April 23, 2019, Art 12 (7))

85 (Liebman, 2007:620,631) 
(iii) New-judges appointed based on quality and skill shall not compromise with independence in the field of adjudicative functions. Second, judges who look for promotion to higher-level courts shall have practical experience at the corresponding junior level judicial courts. ${ }^{86}$ This reform is a way of making an efficient judiciary. Because by judges' experience on lower courts process, working style, and court environment, they well-know the nature of the case, weakness, or gap of judicial procedure that might develop work efficiency in similar nature at higher-level courts. It also reduces the probability of hiring any judge from any courts to accomplish a specific objective. Third, the law has stipulated more responsibilities to judges in the matter of keeping secrets trial works and personal private information with commanding legal consequences to failing. ${ }^{87}$ The conserving secrecy about the secured trial procedure, subtle evidence documents, private information drives to professional and ethical duties of judges. But the scope, context, and contents of secrets issues should be evidently pointed out in the statutory laws. Fourth, judges should exercise adjudicative powers based on facts and laws, directed by independence and impartiality. ${ }^{88}$

Besides the Constitutional statement, this statutory legal emphasis regarding impartial, fair, and independent adjudication system based on facts and law strengthens the standing of de jure judicial independence. In China, substantive independence is closely connected to de jure judicial independence. ${ }^{89}$ The upholding healthy de jure independence unlocks the entrance to implications of de facto independence at an individual level. The concept of substantive judicial independence denotes that judges should perform adjudicative duties subject to no other authority but based on facts, law, and their conscience in the matter of dispute settlement and decisions making process. Also, at the time of application of adjudicative duties, judges should not be subject to interference from administrative bodies, organizations, and individuals. Thus, the modified Judges Law has strongly affirmed the preserving substantive judicial independence in Chinese courts.

(Judges Law of the People's Republic of China amended on April 23, 2019:Art 17)

(Judges Law of the People's Republic of China amended on April 23, 2019, Art 10(5))

88 (Judges Law of the People's Republic of China amended on April 23, 2019,Art 6 and 7)

(Feng, 2016: p.14) 


\section{Conclusions}

The efforts to preserving judicial independence seem like the culture of civilized and democratic nations, and it represents the nations' respect to the fundamental values of the administration of justice. The reforms of the judiciary in China are an ongoing process to ensure a transparent trial procedure, public confidence, and economic growth. It is eminent that the CCP has continuously initiated to make reforms in the judiciary to enhance judicial independence, impartiality, and accountability that could promote the wide-ranging rule of law, social security, and financial development. The significant reforms cover consolidating the funding of courts, splitting adjudicative work from administrative, announcing a life-time responsibility scheme, increasing judicial wages, and decreasing the quantity of employees in courts with the rank of the judge. The reform about appointed process of new judges produces better-qualified judges into the adjudication process with legal skill and professional knowledge. As per new reforms initiatives, only judges are sanctioned to settle cases, and individual judges (not the division head or other leadership within the court) must approve their own verdicts. ${ }^{90}$ Thus, all of these reforms in the judicial sector ultimately promote impartiality, progress professionalism, and strengthen the independence of the judiciary.

China's reforms of laws and judiciary must harmony with their "national conditions", 91 and reform policies have to be implemented under the CCP's headship; usually they do not allow any matters to undermine the Party's leadership. ${ }^{92}$ The improvements not only the basis of expectations and representative goals, but it never rescinds the fundamental national identity. All laws and courts are a reflection of "national goals and identity". Hence, China's court or judicial reforms have often been imbedded in the linguistic of national aims. Any proposed changes that challenge Party goals and national identity fixed by the Party are predestined to fail. ${ }^{93}$ In conclusion, all reforms concerning the trial, court administrations, the jurisdiction of courts, reducing interference from the internal side of the courts, and court accountability have been measured as the way of strengthening of judicial independence in China. Scholars remark that various rounds have made many measures of judicial reform that will passage the Chinese judiciary closer to unaffected judicial independence. This study also receives a similar position in these endeavors.

90 (Wang, 2017:p. 20)

91 (Liebman, 2007: p. 621)

92 Peter CH Chan, "An Uphill Battle: How China's Obsession with Social Stability Is Blocking Judicial Reform," Judicature 100, no. 3 (2016).

93 (Woo, 2017:p. 242) 


\section{References}

Akkas, Sarkar Ali. Judicial Independence and Accountability: A Comparative Study of Contemporary Bangladesh Experience. Wollongong: University of Wollongong, 2002.

Chan, Peter CH. “An Uphill Battle: How China's Obsession with Social Stability Is Blocking Judicial Reform.” Judicature 100, no. 3 (2016).

Chunying, Xin. “What Kind of Judicial Power Does China Need?” International Journal of Constitutional Law 1 (2003).

Council, Canadian Judicial. Why Is Judicial Independence Important to You?"Judicial Independence in Canada. Canada, 2016.

Council, State. "Whitepaper on Judicial Reform in China."

Feng, LIN. The Future of Judicial Independence in China. Centre for Judicial Education and Research, 2016.

Ferejohn, John. “Independent Judges, Dependent Judiciary: Explaining Judicial Independence.” Southern California Law Review 72 (1999): 355.

Gechlik, Mei Ying. "Judicial Reform in China: Lessons from Shanghai.” Colum. J. Asian L 19, no. 1 (2005): 98.

Hailsham, Lord. “The Independence of the Judicial Process.” Israel Law Review 13 (1978).

He, Xin. "The Politics of Courts in China." China law and society review 2 (2017): 135.

Islam, M S. "Independent Judiciary: Nature and Facets from the International Context." International Journal of Ethics in Social Sciences 6, no. 2 (2018): 15-32.

Keyuan, Zou. “Judicial Reform in China: Recent Developments and Future Prospects." Int'l L 36 (2002): 1046.

L.Liebman, Benjamin. “China's Courts: Restricted Reform.” The China Quarterly 191 (2007): 621.

Larkins, Christopher M. "Judicial Independence and Democratization: A Theoretical AndConceptual Analysis.” The American Journal of Comparative Law 444 (1996): 607.

MP Singh. "Securing the Independence of the Judiciary: The Indian Experience." Indiana International Comparative Law Review 10, no. 249 (2000). 
Orts, Eric W. “The Rule of Law in China.” Vand. J. Transnatl. L 34 (2001): 99.

Salzberger, Eli M. "A Positive Analysis of the Doctrine of Separation of Powers, or: Why Do We Have an Independent Judiciary?” International Review of Law and Economics 13, no. 4 (1993): 349-379.

Shetreet, Shimon. "Judicial Independence: New Conceptual Dimensions and Contemporary Challenges." In Judicial Independence: The Contemporary Debate, 398. Dordrecht: Martinus Nijhoff Publishers, 1985.

—. "Judicial Independence and Accountability: Core Values in Liberaldemocracies." In Judiciaries in Comparative Perspective, 3. Cambridge: Cambridge University Press, 2011.

—. "The Administration of Justice: Practical Problems, Value Conflicts AndChanging Concepts." University of British Columbia Law Review 13 (1979): 57.

Shetreet, Shimon and Jules Deschênes. Judicial Independence: The Contemporary Debate. Netherlands: Martinus Nijhoff Publishers, 1985.

Shihao, Hu. "Supreme Court Issues Five-Year Plan on Judicial Reform.” In Supreme People's Court Specials, 2019.

The People's Republic of China. Beijing Statement of Principles of the Independence of the Judiciary (1995), Art. 3(A)., 1995.

—. "Highlights of Work Report of China's Supreme People's Court 2014." Supreme People's Court of the People's Republic of China.

—. Judges Law of the People's Republic of China Amended on April 23, 2019, 2019.

- "Notice of the Supreme People's Court on Issuing the Third Five-Year Reform Outline for the People's Courts (2009-2013)." Supreme People's Court of the People's Republic of China.

—. "Opinions of the Supreme People's Court on Comprehensively Deepening the Reform of the People's Court: Outline of the Fourth Five-Year Reform of the People's Court (2014-2018)." Supreme People's Court of the People's Republic of China.

—. "Second Five Year Reform Program for the People's Courts (2004-2008)." Supreme People's Court of the People's Republic of China.

—. "SPC's White Paper Remarks, the Direct Adjudication by a Sole Judge or a Panel in the 
Shanghai Courts Reach 99.9 per Cent, and Only 0.1 per Cent Referred to the Discussion by the Adjudication Committee." Supreme People's Court of the People's Republic of China.

. "Supreme Court Issues Five-Year Plan on Judicial Reform : Highlights of 2019 SPC

Two Sessions (Hereinafter SPC Latest Five-Year Plan)." Supreme People's Court of the People's Republic of China.

- The Five-Year Program for Reform of the People's Courts. Gazette of the Supreme

People's Court of the People's Republic of China. Gazette of the Supreme People's Court of the People's Republic of China, 1999.

—. "The Intermediary People's Court of Yinchuan, Capital of Ningxia Hui Autonomous Region, Is One of the Courts That Promoted the Invitation to Attend People in Court Hearings." Chinese Courts Invite Citizens to Courtrooms.

—. "The Second Five-Year Reform Plan of the People's Courts (2004-2008)." Supreme People's Court of the People's Republic of China.

_. "The Supreme People's Court Issues Its Newest Five-Year Reform Plan for the Courts." Supreme People's Court Monitor.

—. UN Basic Principles on the Independence of the Judiciary (1985), Art. 2, 1985.

—. Universal Declaration on the Independence of Justice 1983 Art. 2.02, 1983.

—. "Whitepaper on Chinese Court Judicial Reform (2014-2018)." Supreme People's Court of the People's Republic of China.

- "Whitepaper on Court Reform in China." Supreme People's Court of the People's Republic of China.

—. "Whitepaper on Judicial Reform of Chinese Courts." Supreme People's Court of the People's Republic of China.

The People's Republic of China, State Council. "White Paper: Judicial Reform in China, Information Office of the State Council." Information Office of the State Council.

Wang, Yifan; Sarah Biddulph and Andrew Godwin. A Brief Introduction to the Chinese Judicial System and Court Hierarchy. Melbourne: Melbourne Asian Law Centre, Melbourne Law School, The University of Melbourne, 2017. 
Woo, Margaret YK. "Court Reform with Chinese Characteristics.” WASH. INT'L L.J. 27, no. 1 (2017): 247.

Yanrong, ZHAO. "The Way to Understand the Nature and Extent of Judicial Independence in China." Asian Journal of Law and Society (2018): 3. 